\title{
THE UNPRIVILEGED EXILE: FROM NOSTALGIA TO ANTINOSTALGIA AND BEYOND
}

\author{
Jora VASO (Pomeranian University in Słupsk) \\ ORCID: 0000-0002-6785-3951
}

\begin{abstract}
"Nostalgia," writes Antonio Prete quoting Niccolò Tommaseo, "is the noble privilege of poor countries." Though both exile and nostalgia may befall those from more affluent countries and cultures, the conditions are noble and privileged only for those who hail from less developed countries which, as Witold Gombrowicz notes when referring to Poland, have "a minor role,", are doomed to imperfection and produce less sophisticated men. Polish poet Zbigniew Herbert and his Albanian counterpart, Gëzim Hajdari, share a similar fate to that of Gombrowicz as they also struggle with the inherent inferiority of their homelands and, consequently, have difficulties finding a clear position as writers in a global sense. Joseph Brodsky defines this position in more universal terms stating that "the truth of the matter is that from a tyranny one can only be exiled to a democracy." "Thus, Brodsky implies that the departure from any country signifies an escape from overbearing or threatening circumstances toward bearable and safer ones. Brodsky also suggests that, while the condition of exile is relative and encompasses vastly different experiences, all of these differences entwine with each other and become reduced to this common experience. However, the experiences of exile are not the same. Those from more developed regions experienced un-nostalgic and voluntary exiles during the $19^{\text {th }}$ century, where the longing was directed forward, toward the destination that would bring freedom from the tyranny of development. This process was at the very core of Romanticism. Jean Starobinski notes that "the English, in order to heal their spleen, would flee from their native air and
\end{abstract}

\footnotetext{
${ }^{1}$ Antonio Prete, "L'assedio della lontananza," in Nostalgia: Storia di un Sentimento, ed. Antonio Prete (Milano: Raffaello Cortina Editore, 1992), 16: "La nostalgia è nobile privilegio dei paesi poveri."

${ }^{2}$ Gombrowicz, Testament, 56.

${ }^{3}$ Joseph Brodsky, "The Condition We Call Exile: An Address," in Altogether Elsewhere, ed. Marc Robinson (San Diego: Harcourt Brace \& Company, 1994), 4.
} 
depart on their grand tour in search of the serene air of the South, while others," the latter being those from poorer regions, "believed they would be risking death even if they only departed from familiar landscapes!, ${ }^{, 4}$ confirming the difference in perception and, therefore, vastly disparate levels of suffering among the populations of different countries. For the English, the developed democracy became the tyranny from which they needed to escape from time to time and the more primitive villages epitomized this freedom. This tendency, somewhat paradoxically, points to the beginnings of antinostalgia, a modern sentiment which, according to Polish-Jewish writer Henryk Grynberg, entails a purposeful and lucid understanding and recollection of one's birthplace. Antinostalgia is what the English may have only slightly touched upon when they sought escape from their industrial cities in the $19^{\text {th }}$ century and what was to be profoundly felt centuries later from those exiles who hail from less developed, but increasingly developing, European countries. With very few exceptions, the level of development or affluence of a certain country is closely linked to the profundity of nostalgic or antinostalgic feelings experienced by the exiles. Modern development has led to an informed exile who, unlike Odysseus, is determined to not return but who nonetheless experiences that ancient attachment to the birthplace. A contemporary exile from a less privileged country is excessively aware of his country's shortfalls, the birthplace no longer being an object of nostalgia but one which inspires critical recollection. The rise of antinostalgic exiles in the $20^{\text {th }}$ and $21^{\text {st }}$ centuries, like Witold Gombrowicz, Henryk Grynberg, and Gëzim Hajdari, may be an indication of the future of nostalgia or, more specifically, antinostalgia as the nostalgia of present times. Like nostalgia in antiquity, antinostalgia becomes the noble privilege of "poor countries" in present times. More precisely, it becomes the sentiment of those particular exiles whose vehement ties to their birthplace support the continuation of their exile instead of inspiring them to return, as these same ties would for nostalgic exiles.

Nostalgia, the ancient "ache to return," has transformed into antinostalgia, the aim to never return, but to actively remember and, by remembering, preserve the ties to one's birthplace, if only to keep the exile from returning. Memory, however, according to Vladimir Jankélévitch, impoverishes the exile, steals their time, and pushes them toward, but does not prepare them for, failure. By sufficiently feeding the exile without granting full satisfaction, memory or nostalgia imprisons the exile. As noted by Jankélévitch, "by leaving us memories, that is, substitutes for the present, the time that passes throws us a bone to gnaw on: the unfulfilled remains hungry. Such is the misery of memory. ${ }^{5}$ Memory is a quite miserable consolation which can neither reverse the irreversible nor fill our poverty or compensate for our state of insufficiency. In this respect, memory is a broken promise, a disappointment and a failure. ${ }^{\prime 6}$ Jankélévitch refers to nostalgic memory, which romanticizes the birthplace and creates an idealized,

${ }^{4}$ Jean Starobinski, "Il Concetto di Nostalgia," in Nostalgia: Storia di un sentimento, ed. Antonio Prete (Milano: Raffaello Cortina Editore, 1992), 92: "Gli inglesi, per guarire dal loro spleen, fuggivano l'aria natale e partivano per il loro grand tour alla ricerca dell'aria serena del Sud, mentre altri credevano di esporsi al rischio della morte se soltanto si alontanavono dai paesaggi familiari!”

${ }^{5}$ Vladimir Jankélévitch, L'irréversible et la nostalgie (Paris: Flammarion, 1974), 314: "En nous laissant des souvenirs, c'est-à-dire des succédanés de la presence, le temps qui passe nous jette un os décharné à ronger: l'inassouvi reste sur le faim. Telle est la misère du souvenir,"

${ }^{6}$ Ibid: "Le souvenir est une fiche de consolation assez miserable et qui ne peut ni renverser l'irréversible ni combler notre indigence ni compenser notre état d'insuffisance. Le souvenir est à cet égard une promesse non tenué, une déception et un échec." 
unreachable object that exists solely in one's memory. Antinostalgic memory is not entirely different in that it also imprisons the exile, whose primary preoccupation becomes not the present life or place but the former life and country, as it does in nostalgia. In contrast to nostalgia, however, antinostalgia fanatically maintains an antiromanticized record of the birthplace in order to prevent both returning to it and forgetting about it. This aim paradoxically roots the exile in the past as it represents a figurative return and a backward glance.

The conditions of nostalgia and antinostalgia are both significantly more present and more complex for an exile from a poorer country because they combine the real or perceived impossibility/risk of return and the desire/lack of desire for it. In the case of nostalgia, attachment to one's birthplace or object of longing grows and intensifies exponentially with the impossibility of return or acquisition of the aforementioned object, resulting in its glorification. For the exiles from poorer countries, the idea of exile has historically carried a sense of finality and a probability, if not certainty, of one never returning to one's roots. This adds a significantly heavier, more tragic aspect to the unprivileged exile's nostalgia than to that of the English, who set out towards the countryside to satisfy their nostalgia for a simpler life. What further emphasizes the general intractable nature of the unprivileged exile's situation is that nostalgia, like love, is irrational: "it is disproportionate to its cause," suggests Jankélévitch, and it becomes furthermore, "the cause of its own cause." It would seem that if nostalgia resembles love, antinostalgia becomes hate. However, nostalgia and antinostalgia are neither opposites nor interchangeable. Antinostalgia is an extension of nostalgia, a modern phenomenon which connects the ancient condition to contemporary exile, the tool of the exile who should sever all ties with the birthplace but cannot. They are linked through the individual's profound attachment to the birthplace but, whereas nostalgia is purely irrational, antinostalgia is an attempt to rationalize and, thus, control the irrational. At their very root, both nostalgia and antinostalgia carry within them a fear of taking responsibility for the present. According to Svetlana Boym, nostalgia can be "an abdication of personal responsibility, a guilt-free homecoming," 8 or otherwise stated, an impossible return to innocence. "The nostalgic desires to obliterate history and turn it into private or collective mythology, to revisit time like space, refusing to surrender to the irreversibility of time that plagues the human condition," Boym adds. Indeed, the antinostalgic, who desires to change or affect history retroactively by exposing it, reveals the same inherent desire at the root, that of a return in time, and the same inability, that of moving forward toward an exploration of the self. It is precisely this exploration of the self, undertaken by the European Romantics, that eluded the unprivileged exiles, or the exiles from countries where Romanticism did not occur or took on a nationalistic and, perhaps moralistic, form.

Jean Starobinski, citing Rochefoucauld, explains that "there are people who would have never fallen in love had they never heard of love as a subject of discussion."10

Similarly, the early assumption that nostalgia was incurable, as it was presumed

\footnotetext{
${ }^{7}$ Ibid, 352; "parce qu'elle est disproportionnée avec sa cause, [...], parce qu'elle est ellemême la cause de sa propre cause."

${ }^{8}$ Svetlana Boym, The Future of Nostalgia (New York: Basic Books, 2001), 22, iBooks.

${ }^{9}$ Ibid, 25.

${ }^{10}$ Starobinski, "Il concetto di nostalgia," 86: "Ci sono persone che non si sarebbero mai innamorate se non avessero sentito parlare dell' amore."
} 
before the condition made its journey from a fatal disease to a sentiment, ${ }^{11}$ did indeed cause deaths. Indeed, it took several centuries for nostalgia to become the nearly harmless sentiment that it is today, a result partly due to the development of nostalgia as an object of study: "When the young Hofer proposed to the academics at Basel to substitute Heimweh with the new word nostalgia [in 1688], on the one hand, he expanded the medical catalogue of the condition of suffering, on the other hand, he diluted the concreteness and polysemy of Heim' into the indefinite form of desire." ${ }^{\prime 2}$ Thus, nostalgia and melancholia join as condition-sentiments rooted in the desire for the other, the elsewhere, the before, or the better, accompanied by the foreboding that there is no cure, no escape, no return, no remedy. As such, even the French who, according to Jean-Jacques Rousseau, live "in the best country on earth, in which all the comforts and pleasures of life contribute to the well-being of its inhabitants," and have never had any cases where "hearing those songs of the mountains made a French man, who lives in foreign land, cry or die of nostalgia,"13 claim a poet like Charles Baudelaire, whose melancholia he finds in his own city. Baudelaire's condition is melancholia as, unlike nostalgia, it lacks a specific object. Indeed, the exile of the $19^{\text {th }}$ century, who lives in an economically developed country, cannot claim the "privilege" of nostalgia but experiences more abstract, object-less longings. Baudelaire's "real travelers," the ones "who leave / In order to leave; light hearts, similar to balloons, / They are never separated from their fate, / And, without knowing why, always say: Let us go on!"14 are those from more developed countries. "Leaving in order to leave" has become available to Eastern European countries only in the last several decades. Hailing from a less developed European country in the $20^{\text {th }}$ century dictates that one must physically travel in space and, thus, time, to reach the same conclusions that, to a Parisian of the $19^{\text {th }}$ century like Baudelaire, become apparent while strolling in the streets of the city. When he penned his poem "The Swan" in 1857, Baudelaire wrote of conditions which, for Gombrowicz, Herbert, and Hajdari, only the first-person experience of exile would elucidate, almost a century later.

"The valuation of one's native land takes on a passionate element in the $19^{\text {th }}$ century, initially in the generation of the romantics and, subsequently, after the revolution of 1848 , when the idea of nationalities and the modern forms of patriotism penetrate Europe and its conscience,"15 explains Vladimir Jankélévitch. It was during

${ }^{11}$ Antonio Prete's collection recounts the history of nostalgia, specifically from the condition's initial appearance as a fatal disease in the $17^{\text {th }}$ century until its abstraction and eventual transformation into a sentiment in the $20^{\text {th }}$ century.

12 Prete, "L'assedio della lontananza," 11-12: "Quando il giovanne Hofer propone agli accademici di Basilea di sostituire Heimweh con la nuova parola nostalgia [in 1688], da una parte egli enlarga il catalogo medico delle sofferenze, dall'altra stempera la concretezza e la polisemia di Heim nella forma indefinite del desiderio."

${ }^{13}$ Jean-Jacques Rousseau, "Il suono natio: Jean-Jacques Rousseau," transl. Antonio Prete, in Nostalgia: Storia di un sentimento, ed. Antonio Prete (Milano: Raffaello Cortina Editore, 1992), 68: "nel miglior paese del mondo, nel quale tutte le comodita e tutti i piaceri della vita concorrono al benessere degli abitanti, l'ascolto di canzonetta di montagna abbia fatto piangere o morire di nostalgia une francese che si trova in terra straniera."

${ }^{14}$ Charles Baudelaire, Flowers of Evil and Other Works/Les fleurs du mal et oeuvres choisies: A Dual Language Book, ed. and trans. by Wallace Fowlie (New York: Dover Publications, 1963), 94: "vrais voyageurs [...] qui partent / Pour partir; coeurs légers, semblables aux ballons, / De leur fatalité jamais ils ne s'écartent, / Et, sans savoir pourquoi, disent toujours: Allons!"

${ }^{15}$ Jankélévitch, L'irréversible et la nostalgie, 343: "La valorisation de la terre natale prend un sens passionné au XIX ${ }^{\mathrm{e}}$ siècle, d'abord dans la génération romantique, et ensuite après la 
the mid-1800's, Jankélévitch writes, that exiles like Victor Hugo exclaimed one can no more live without one's country than without bread. While the movement reverberated across Europe and grew to include an element of individual subjectivity, only the faintest echoes, namely the patriotic elements, were felt in its less developed regions. And while the patriotic element was felt in the works of Polish Romantic poet, Adam Mickiewicz, the subjectivism that accompanied late Romanticism in Great Britain, with poets like John Keats and William Wordsworth, took more than a century to begin making its way to countries like Albania and Poland. In Poland, Romanticism coincided with the rest of Europe, with Adam Mickiewicz's patriotic, epic poem Pan Tadeusz first published in 1834 in Paris. Because of his works' patriotic nature, the figure of Mickiewicz as a Polish national icon attests to an inextricable link between romanticism and nationalism, mirroring the European Romantic movement only in its very early stages. Unlike in Europe, however, Romanticism in Poland did not quite evolve away from the patriotic and into the subjectivism of poets like Wordsworth or Keats. Mickiewicz's longstanding influence, one which spurred protests when his plays were censored by the Communist regime in Poland, points to the remnants of the nationalist nature of Romanticism in Poland and its enduring claim on Polish literature. While the poet was considered the greatest of "Poland's romantic poet-visionaries," Mickiewicz became responsible for "an inexhaustible duty inheritance to which every Pole had the right, indeed, the (patriotic) duty, to lay claim." ${ }^{\text {"16 }}$ It is this lack of evolution from patriotism to subjectivism, because of this somewhat stagnant remnant from Romanticism, an encumbering duty inherited from Mickiewicz which every Polish writer owes his country, that inspires Witold Gombrowicz's revolt against Polish literature. Romantic poets, according to Maria Janion, had a clear vision of restoring the "forgotten greatness" of "Slavdom" to Poland through the use of "native folk art and its transformations." 17 It is the acceptance of what Janion refers to as Poland's "uncanny Slavdom" that can yield to a more accurate, perhaps updated, position for Poland. This awareness, suggest Janion, "may allow for an alternative reflection on our place in Europe. It does not have to be determined by a clear line delineating the East and the West. Poland does not have to boast its 'Western' character, it can freely embrace the 'Eastern' self. The latter will not be detrimental provided that our social leaders perform certain intellectual operations resulting in an understanding of its own position and prejudice." 18

According to Gombrowicz, the after-effects of Romanticism, in Poland's lack of clear position and failure to fully understand itself, hindered the Polish writers of the $20^{\text {th }}$ century from reaching their highest potential. Gombrowicz claims that Romanticism in Poland not only did not yield a less nationalistic future national oeuvre but helped preserve an element that precluded the individual from creating original work, what Janion claims is this preservation of Slavdom and Gombrowicz deems as a nationalistic duty. While Romanticism as a literary movement in Poland did occur, Witold Gombrowicz denies the "European" aspect of it. "None of the great movements

revolution de 1848, quand le principe des nationalités et les formes modernes du patriotism accèdent en Europe à la conscience de soi."

${ }^{16}$ Roman Koropeckyj, "Adam Mickiewicz as a Polish National Icon," in History of the Literary Cultures East-Central Europe, ed. Marcel Cornis-Pope and John Neubauer (Amsterdam: John Benjamin's Publishing House, 2004), 22.

${ }^{17}$ Maria Janion, "Poland Between the East and the West," transl. Anna Warso, Postcolonial or Postdependancy Studies 1 (2014): 19.

${ }^{18}$ Janion, "Poland Between," 21. 
of European culture has ever really penetrated Poland," Gombrowicz confesses, "not the Renaissance, not the wars of religion, not the French revolution, not the Industrial Revolution. Of all these phenomena, Poland has felt no more than a muted echo."19 This "muted echo" suffices to preserve the position of Poland as peripheral, neither central, nor entirely detached.

Gombrowicz found his place among the "cattle country" 20 of Argentina which "had no appreciation of literature" 21 more than in his own continent. He left Poland before World War II broke out in 1939, in a spontaneous decision, invited on the ship Chrobry's maiden voyage to Argentina. Of the decision to leave, and the unlikely outcome of him taking this departure to its conclusion, he implies that, though he had wanted to leave Poland, it was not to escape the war: "I prepared for the journey quite casually and it was by chance alone (chance?) that I didn't remain in Poland." ${ }^{22}$ Yet, escaping the war by a week, he feels that he was saved from Poland, a feeling he shares with Grynberg: "It was as though an enormous hand had seized me by the collar and, lifted me out of Poland and placed me in this lost land in the middle of the ocean," 23 Gombrowicz writes. Though under objectively unequal levels of threat while in Poland, what joins the authors is their quest for self-preservation. "I thank Almighty God that he got me out of Poland when my literary situation began to improve and cast me onto American soil, into a foreign tongue, into isolation, into the freshness of anonymity, into a country richer in cows than in art, ${ }^{, 24}$ The art of Poland is encumbered, his identity already consumed by criticism, and the Polish tongue soiled by its context. For a man who saw his writing as the reflection of his entire identity — "my writing must become myself," 25 — this lack of freedom or anonymity directly threatened him, something Gombrowicz naturally did not accept. Among Poles, Gombrowicz could not have become himself, as he desired. In Poland, he felt he was doomed to the inescapable prison of unoriginality, caused by inferiority. His exile to Argentina was a quest to save the original in him, to preserve what he could offer the world not as a Pole but as a man who happened to be a Pole:

To break away! To keep one's distance! The writer, the artist, or anyone who attaches importance to his spiritual development, must feel no more a resident in Poland or the Argentine, and it is his duty to regard Poland or the Argentine as an obstacle, almost an enemy. That is the only way to feel really free. And only those people for whom their country is an obstacle rather than an advantage will have a chance of becoming truly free spiritually. ${ }^{26}$

The birthplace as obstacle becomes an especially complex issue for Gombrowicz as the country's foundations for art are unoriginal and its aims misguided. "With our halfFrench Chopin and not quite native Copernicus, we cannot compete with the Italians, French, Germans, English or Russians,"27 Gombrowicz writes. Aware of the unprivileged or, alternatively, less central position that Poland has granted its writers,

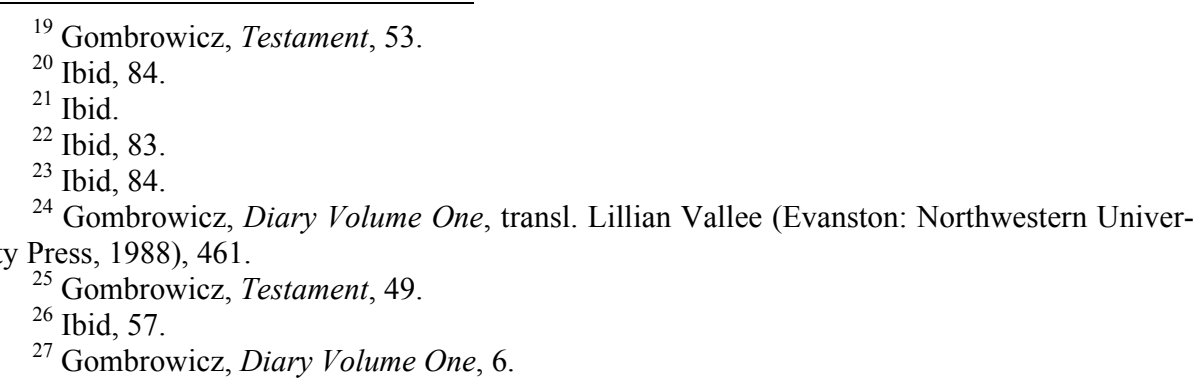


Gombrowicz condemns those who attempt to match or approximate artists from privileged, or culturally central, nations. "It is exactly this approach that condemns us to inferiority," 28 writes Gombrowicz, suggesting that Poland should follow its own, original, course and, in a way, "sacrificing" himself in order to demonstrate it can be accomplished.

A half century following Gombrowicz' claims, in an interview from 2000, Clare Cavanagh, one of the main translators of Polish poetry into English, confirms: "The Poles have an inferiority complex" though their literary criticism, for instance, "is better than American literary criticism. $" 29$ As late as during the last few decades, the Poles "are very much dealing with the main European trends that have come along, particularly from France, and they're overwhelmingly aware of where the totalitarian and utopian ideologies have led to in the Polish context: on their own skin, literally." The totalitarian system, which touched both Poland and Albania, served to retain, and further enforce, the patriotic element of Romanticism. Regarding Poland, Miłosz explains the complications caused by the Poles' patriotic duty, mainly the resulting blindness and creation of distance from the self: "Communism was fighting Fascism; and the Poles, with their ethical code based on nothing but loyalty, had managed to thrust themselves between these two forces." 31 This patriotic duty transmitted through Polish Romantic poetry and preserved through centuries has been highlighted by "a number of researchers (Bromke, Bocheński, Ciechanowski, Janion)," all of who "have pointed out that Romantic tradition transmitted by literature was as a source of inspiration for the young soldiers of the resistance movement in Poland, especially for the insurgents fighting in the Warsaw Rising of 1944."32 Gombrowicz bemoans this patriotic vein in the history of poetry, this appeal to the collective, or even call to arms, rather than the reflection of the individual, one's subjective truth and experience, aspects of the European Romanticism. Gombrowicz's reply to this limitedness, which he claims results from one's insistent loyalty to one's roots, is that "each person is responsible only for himself.",33 "I was Polish. I happened to be in Poland. What is Poland? It is a country between the East and the West," ${ }^{34}$ he states, attributing to Poland a feebler significance than it perhaps truly had. Yet, in this manner, Gombrowicz is quicker in capturing the elusive effects of those "grand European movements" of which his country had robbed him, bypassing his perceived lack of Romanticism and, along with it, swiftly overcoming nostalgic longings and the excessive attachment of antinostalgia, in search of himself. ${ }^{35}$ Nonetheless, Gombrowicz, does struggle to develop his own style, one which is neither Polish nor non-Polish, un-Polish, or anti-

\footnotetext{
${ }^{28}$ Ibid.

${ }^{29}$ Clare Cavanagh, "An Interview with Clare Cavanagh," interview by W. Martin, Chicago Review: New Polish Writing 46, no. 3 \& 4 (2000): 92.

${ }^{30}$ Ibid, 92.

${ }^{31}$ Czesław Miłosz, The Captive Mind, transl. Jane Zielonko (New York: Vintage Books, 1955), 93, iBooks.

32 Barbara Törnquist-Plewa, "Romanticism and Realism in Poland," Scando-Slavica 40

${ }^{33}$ Gombrowicz, Diary Volume One, 7.

${ }^{34}$ Gombrowicz, Testament, 53.

${ }^{35}$ It is important to note that this tendency to leap ahead of others, not only unencumbered by a patriotic duty but deliberately defying his country, may be due to his privileged upbringing within Poland, a factor which places him closer to Western writers, in terms of freedom, than one may assume.
} (1994). 
Poland, neither European, nor non-European. His stance does not follow the traditional one of favoring the West, as scholar Maria Janion suggests: "Poland has found itself in an east-western position, or, as Sławomir Mrożek ironically observed, located to the west from the East and to the east from the West. However, it has mostly sought, with the thought of its intellectuals, to outweigh the balance in favor of 'the West' and to disassociate itself from 'the East,", 36 especially Russia but also, in more abstract terms, the idea of the East.

While Gombrowicz acknowledges that Polish writers cannot altogether reject their nationality, Gombroowicz bemoans a general lack of originality among them as much as he condemns the Polish public for their excessive praise of the main figures of Romanticism, Adam Mickiewicz and composer Frédéric Chopin. For Gombrowicz, it is precisely this that reveals Poland's tendency toward the West. "The price for structural assimilation of 'our countries' into the Western model was often very high, but it was a necessary condition for their great and comprehensive development," 37 writes Janion, referring to Poland's case of "Orientalism," as elucidated by historian Jerzy Kłoczowski. Gombrowicz believes that this "basking in their own culture," in order to "match" the West, ultimately results in "baring their primitiveness." 38 However, part of Gombrowicz's unwavering determination to speak only for himself may also stem precisely from this inescapable inferiority. He seeks his own style so adamantly because he is certain that, for the Polish writer, though no less for the European one, unless one breaks away from Poland or one's origins, one will never "have a chance of becoming truly free spiritually, and, in the case of Europe, truly European." 39 While acknowledging Poland's self-perpetuated inferiority, Gombrowicz also clarifies the reasons behind it:

To compare Mickiewicz to Dante or Shakespeare is to compare fruit to preserves, a natural product to a processed one; a meadow, field, or village to a cathedral or city; an idyllic soul to an urban one which is rooted in people, not in nature, which is loaded with knowledge about the world of the human race. Was Mickiewicz less great than Dante? If we have to give ourselves up to these gauges, let us say that he looked at the world from gentle Polish slopes while Dante was elevated at the peak of a mighty mountain (made of people), from which he had access to other perspectives. Dante, while not being perhaps 'greater,' was poised higher: this is why he has the advantage. ${ }^{40}$

In A Kind of Testament, the Polish author confesses that only following the completion of his novel Ferdydurke, which served to confirm that he had "nothing in common with Communism or Nazism, or any Dadaism or Surrealism," $" 41$ and thus, having no allegiance to any particular system or movement, does he finally feel European, more than European. "After that," he adds "throughout my life, during twenty-three years of the Argentinian pampas or anywhere else, I never lost the certainty that I was European, more European perhaps than the Europeans of Rome or Paris." 42 Because loyalty to Poland necessarily entails submission to the West and acceptance of one's position as a follower or imitator, Gombrowicz detached himself from his homeland as if from a sinking ship. As a Polish writer, he continued struggling with this complex

\footnotetext{
${ }^{36}$ Janion, "Poland Between," 13.

${ }^{37}$ Ibid, 24

${ }^{38}$ Gombrowicz, Diary Volume One, 4.

${ }^{39}$ Gombrowicz, Testament, 57.

${ }^{40}$ Gombrowicz, Diary Volume One, 4-5.

${ }^{41}$ Gombrowicz, Testament, 63.

${ }^{42}$ Ibid, 63.
} 
but, as an individual without a country to defend, he attempted to overcome it. "What liberty, then!" he continues "And how satisfying to talk on equal terms with the madonnas, to approach the masterpieces disrespectfully, to have the whole of Rome at my feet." 43 Does this defiance reflect an inferiority complex? According to Cavanagh, in Poland, contemporary authors "have a complex about the West, that they're never up to par with it, that they're always following somebody's fashion, that they're the parrot of Western trends." " Indeed, the persistence is also present in Gombrowicz's desire to "demean" Europe, a stance that paradoxically both betrays and confirms his Polish identity.

Unlike Poland, Albania did not undergo the major European movements of the Enlightenment and Romanticism, indicating not only the country's lack of development and industrialization in the $19^{\text {th }}$ century, but, most importantly, the resulting absence of sensitivity, self-awareness and subjectivity in the country's literature, which would begin making an appearance almost two centuries later. A survey of Albanian literature reveals an oeuvre that is, as a result of the country's history, at best, incomplete and, at worst, amputated or disrupted. One of the main reasons is that "the Ottoman Empire, which ruled Albania from the $15^{\text {th }}$ to the early $20^{\text {th }}$ century, prohibited publications in Albanian, an edict that became a serious obstacle to the development of literature in that language. Books in Albanian were rare until the late $19^{\text {th }}$ century." 45 Thus, for five centuries, including the period during which western European countries were undergoing the Enlightenment and Romantic literary movements, in addition to not being exposed to the West, Albania was also entirely absent from the global literary scene. That Albanian literature survived is almost entirely owed to the national nostalgic authors who lived outside of its borders. Indeed, almost no part of Albania's identity was created from within Albania. It has historically come from outside of the country, either by the country's most famous exiled poets or western travelers of the Romantic period, such as Lord Byron and Edward Lear. Initially, the survival of Albanian literature, came from outside of its borders in the form of Arbëresh writers, artists and poets who had migrated from Albania to Italy centuries earlier. Chief among them was Jeronim de Rada (1814-1903), considered the greatest Albanian Romantic poet and one who, more than others, "marked contemporaneity with European developments" ${ }^{46}$ with his long poem The Songs of Milosao of 1836. While de Rada's poetry is not similar to the European Romantics, some romantic elements such as the "return to feeling, to folk traditions," 47 are present. It was not in the poems of de Rada that Albanians first found Romanticism, in terms of content and style, but, two decades later, in those of exiled poet Naim Frashëri. Similar to de Rada, Naim Frashëri ${ }^{48}$ was

\footnotetext{
${ }^{43}$ Ibid.

${ }^{44}$ Cavanagh, Interview, 87.

45 Peter R. Prifti, "Albanian Literature," Encyclopaedia Britannica, Jul 20, 1998. https://www.britannica.com/art/Albanian-literature.

${ }^{46}$ Vjollca Dibra, "Albanian and English Literature in Light of Comparative Reports," Academic Journal of Interdisciplinary Studies 2, no. 4 (2013): 80, https://nanopdf.com/download/albanian-and-english-literature-in-light-of-comparative-reports_pdf.

${ }^{47}$ Harold Bloom, Lionel Trilling, "Romantic Poetry and Prose," in The Oxford Anthology of English Literature (New York: Oxford University Press, 1973), 4.

${ }^{48}$ Naim Frashëri (1846-1900) is considered the greatest Albanian poet. Though writing in the late $19^{\text {th }}$ century, Frashëri is considered a Romantic poet in Albania and is the link between the Albanian Romantics and the post-Romantic movement of the Renaissance, seldom described as Romantic Nationalism.
} 
also influenced by the European Romantic poets ${ }^{49}$ and is considered the Albanian Romantic poet, a title given him mainly due to his style of verse as, in temporal terms, he wrote more than a century after the European Romantics. Unlike de Rada, Frashëri was born in Albania but, with the exception of a short return to his native village of Frashëri, he lived the rest of his days in exile. His poetry, though more modern than his predecessors', remains highly patriotic. In his most famous poem Bagëti dhe Bujqësi (Cattle and Farming), written in 1886, Frashëri writes:

Kur dëgjon zëthin e s'ëmës qysh e le qengji kopenë,

Blegërin dy a tri herë edhe ikën e merr dhenë,

\section{$[\ldots]$}

Mendje! merr fushat e malet, jashtë, jashtë nga qyteti,

Nga brengat, nga thashethemet, nga rrëmuja, nga rrëmeti.

Tek këndon thëllëza me gas edhe zogu me dëshirë,
When he hears his mother's voice, how the lamb runs from the herd

he starts bleating twice or thrice and runs wildly towards her.

[...]

Mind! Run to the fields and mountains, out, out from the city

From all sorrows, from the gossip, from the chaos and hypocrisy

To that place where the partridge sings with joy and the bird so longingly ${ }^{50}$

This poem of longing for the homeland lent Frashëri his status as the Albanian national poet. His highly patriotic and nostalgic poems are a far cry from those of the contemporary exiled Albanian poet, Gëzim Hajdari.

Gëzim Hajdari was born in the small village of Hajdaraj in Darsia, Lushnja in Albania, in 1957. During Enver Hoxha's severe regime, which lasted from 1945 to 1992, his family's property was confiscated and, as it was with other property owners at the time, the Hajdaris were marginalized. After completing his university studies in literature in Elbasan, Hajdari returned to his village of birth. Intent on overthrowing Hoxha's regime, in 1991, Hajdari founded the Republican and Democratic parties in Lushnja and a political-literary journal entitled Ora e Fjalës (The Time of the Word), where he not only vocally opposed Hoxha's regime but recorded and exposed all crimes committed by it. The Communist system was overthrown in 1992 by a new government which Hajdari found equally criminal, as its leaders had long-standing ties to the previous regime. It was due to these events that in April of 1992, Hajdari fled to Italy where he settled in Frosinone. Initially living in abject conditions, Hajdari managed to find work and continue a career as a poet in Italy, where he published works denouncing both Hoxha's and the subsequent government's criminal acts and human rights violations. While in Italy Hajdari is a relatively well-known poet, in Albania he remains mostly unknown. To this day, Hajdari has not returned to Albania.

His poetry is a record of his exile, antinostlagia, and increasing distance between him and is birthplace. It records the evolution of his physical and metaphysical exile. initially entirely devoted to Albania, simultaneously denouncing it and longing for it,

${ }^{49}$ Dibra, “Albanian and English Literature," 82: "Jeronim de Rada mentions Shakespeare, Naim Frasheri, mentions Milton, and Ndre Mjeda, mentions the Irish poet, Charles Wolf. The only English poet that is mentioned by nearly all of our romanticists and the only English poet that is often mentioned, almost as much as Homer, is Byron."

${ }^{50}$ Naim Frashëri, Bagëti e Bujqësi, 1886, https://sq.wikibooks.org/wiki/Bagëti_e_Bujqësi [my translation]. 
his poetry eventually becomes more of a reflection of Hajdari the man and poet, relegating Albania to a secondary position. His entire poetic oeuvre is originally written in both Albanian and Italian. Hajdari's poetry retains the poet's inescapable attachment to his birthplace but, contrary to Frashëri's, focuses on the damaging parts of the homeland. His verse borrows from another iconic, though less-celebrated Albanian poet, Migjeni (Millosh Gjergj Nikolla), who singlehandedly brought the country's poverty to the forefront of national literature. ${ }^{51}$ In contrast to the patriotic-romantic legacy the exiled poet Frashëri had left behind, Migjeni's revolutionary Vargjet e Lira (Free Verse), composed between 1933 and 1935, revealed Albania's reality as recounted from deep within the village. While "previous generations of poets had sung the beauties of the Albanian mountains and the sacred traditions of the nation," Migjeni "now opened his eyes to the harsh realities of life, to the appalling level of misery, disease and poverty he discovered all around him." ${ }^{, 52}$ His long Poema e mjerimit (Poem of poverty) depicts the consequences of Albanians' destitute existence throughout the centuries and the consequent loss of identity - "Edhe shuhet ûja, dhe fashitet etja (And in unbridled lust the thirst is quenched), / N'epshin kapërthyes, kur mbytet vetvetja. ${ }^{53}$ (The craving stilled, and self-consciousness lost.), ${ }^{34}$ - a theme later taken up by contemporary poet Gëzim Hajdari who, though an exile, unlike Migjeni, persistently recalls the self-effacing effect of poverty.

During the Communist period, the village was glorified - despite its poor conditions - as part of the state's propagandistic regime, a propaganda accompanied by strict censorship of those who were considered unpatriotic poets. What once was active censorship of Hajdari's work became a passive indifference in the years of transition to democracy: "I've read my books everywhere/ but in my Albania,", 55 Hajdari confesses. He simultaneously admits to his desire to taste childhood ${ }^{56}$ by reading his "own verses in the birthplace" but is aware of the improbability of this occurring in his lifetime: "others will read them for me,",57 he writes. One of the reasons Hajdari's poetry was marginalized was that, like Migjeni's, it did not celebrate Albania. Throughout the Communist period, the privileged citizens of Albania's capital of Tirana were forcefully sent to villages as a way of equally distributing the nation's population and its human resources but also as a way of constructing the new Socialist hero: "Particularly exalted is the heroic figure of the Albanian men who loses the

\footnotetext{
${ }^{51}$ Robert Elsie, "Introduction,” in Migjeni Free Verse (Peja: Dukagjini, 2001), 7: “Albanian literature was late in evolving. Indeed, it was only in the second half of the nineteenth century that a national literature consolidated in this Balkan nation struggling for freedom from a decaying Ottoman Empire. The spirit of romantic nationalism characteristic of nineteenth-century Albanian literature lingered on in the country even after it achieved independence in 1912. Indeed, the genre survived unscathed up until the 1930s, at a time when the rest of Europe had forgotten its existence. It was a young teacher from the northern Albanian town of Shkodra who finally cast the lofty traditions of national culture aside and altered the course of Albanian literature. With Migjeni, contemporary Albanian poetry begins its course."

${ }^{52}$ Elsie, Migjeni Free Verse, 10.

${ }^{53}$ A more accurate translation of these verses is "when the self is drowned" or "stifled."

${ }^{54}$ Elsie, Migjeni Free Verse, 36-39.

${ }^{55}$ Gëzim Hajdari, Poesie scelte 1990-2015 (Nardò: Salento Books, 2015), 193: "Ho letto ovunque per il mondo i miei libri / ma non nella mia Albania."

${ }^{56}$ Ibid: "leggere i prorpri versi nel paese natale avrebbe il sapore dell'infanzia."

${ }^{57}$ Ibid: "altri li leggerano per me."
} 
characteristics of the warrior to assume those of the laborer." ${ }^{, 58}$ Literature was reserved only for a privileged few and discouraged for most, while people were encouraged to become workers. For those who had only finally become able to live in cities, the sendoff to the villages represented a severe kind of punishment, a much too premature return to the rural life they had only recently willingly relinquished. As such, in many ways, the Communist period was the last act in the removal of any traces of genuine romanticism, or inspiration, that may have organically grown among Albanian poets. So forceful was the Communist propaganda, that exiled Albanian poet Gëzim Hajdari - in a similar manner that Henryk Grynberg compiles the unaltered but rearranged testimonies of Jewish children in his collection Children of Zion - collected hundreds of Communist-era "chilling slogans" 59 in his volume entitled Evviva il canto del gallo nel villaggio comunista / Rroftë kënga e gjelit në fshatin komunist (2013), ${ }^{60}$ which were presented to the Western reader for the very first time. For Hajdari, this represented a way of "confronting the historical truth of the past and not forgetting, until the moment when the Parliament of Tirana condemns the crimes against humanity committed during the Communist dictatorship."61 once more echoing Henryk Grynberg's inescapable duty to remember and report the atrocious events he witnessed in his birthplace of Poland. In his essay "We, the Jews of Dobre," Grynberg describes a class assignment where he chose to write about "those who did not make it," 22 the Jews who died before they could enjoy that beautiful day like the rest of the class. Since then, he confesses, "temat został mi dany, zadany i nigdy mnie nie opuścił / the subject was given to me, assigned to me and it has never left me." ${ }^{\prime 63}$ Grynberg wishes he could forget but he cannot. In the same way that Grynberg hopes to forget and be forgotten his poem entitled "Antynostalgia," yet concludes that forgetfulness, or the lack of it, is reciprocal. The same way he cannot forget the "antyludzi twarzy / antihuman faces" ${ }^{\prime 64}$ he saw as a child in his village, so Poland would have invented him if he were to entirely disappear: "Nie uda mi się / nie mogę zostać zapomniany / bo nawet gdyby mnie zupełnie nie było / oni wymyśliliby mnie." (I will not make it / I cannot remain forgotten / because even if I weren't completely there / they would invent me.)" ${ }^{\prime 65}$ Here, Grynberg may be referring to the fact the figure of the Jew is one which Poland reinvents or sustains as a permanent adversary. With these verses, Grynbers makes the claim that the incapability of letting go is mutual, neither he nor Poland can sever ties with one another. Henryk Grynberg left home "one October morning" $" 66$ and vowed to never return. After having miraculously survived a childhood during the Holocaust, and resolved to nonetheless live in Poland, Grynberg, betrayed

58 Laura Toppan, “Gëzim Hajdari (1957-), il poeta dell'esilio.” Altriitaliani.net, 2009, 1. https://altritaliani.net/wp-content/uploads/pdf_Conf._Laura_su_Hajdari_per_Paris.pdf; "In particolare viene esaltata la figura eroica dell'uomo albanese che perde le caratteristiche del guerriero per assumere quella del lavoratore."

${ }^{59}$ Gëzim Hajdari, Evviva il canto del gallo nel villaggio comunista (Nardò: Salento Books, 2013), 7: "slogan agghiaccianti."

${ }^{60}$ In English: "Long live the song of the rooster in the Communist village."

${ }^{61}$ Hajdari, Evviva, 9: "confrontarmi con la verità storica del passato e per non dimenticare, affinché il Parlamento di Tirana condanni i crimini commessi contro l'umanita durante la dittatura comunista."

${ }^{62}$ Henryk Grynberg, Monolog polsko-żydowski (Wołowiec: Wydawnictwo Czarne, 2003), 90.

${ }^{63}$ Ibid.

${ }^{64}$ Henryk Grynberg, Antynostalgia (London: Oficyna Poetów i Malarzy, 1971), 33.

${ }^{65}$ Grynberg, Antynostalgia, 33.

${ }^{66}$ Grynberg, "We, the Jews of Dobre." 
by Poland for a second time with the anti-Semitic campaign of March 1968, finally went to New York with the Warsaw Jewish Theater in October of 1967, right before the campaign's peak. "After what I had remembered from childhood, I knew I could not endure anything like it a second time. I wasn't afraid. I felt anger [...] I felt contempt. ${ }^{, 67}$ It is this contempt that kept Grynberg permanently in the United States, where he still lives, and lends his anitnostalgia a certain calm resolve. Grynberg is resolved to both cut and never cut ties with his birthplace. However, the mirror image of this resolve is his submission to the idea that Poland will not let him go, regardless of his wish to be forgotten. In this, Gryberg and Poland become one and the same, echoing the simultaneous distance and inseparability between exile and birthplace found in Hajdari's verses: "Hello Albania! I am Albania." 68

It is a certain level of "antihumanity" that also gives rise to Hajdari's antinostalgia, or duty to remember, which goes beyond any attachment one may have to one's home but can only begin from home. "Dove sei fuggita città di Lushnje?" Hajdari asks his birthplace:

\author{
Where do you lie city of the interned? \\ City of thunders and poets, \\ Of folly and suicide. \\ Why this silence city of Lushnje? \\ City of arrests in the dead of night \\ Of hangings and barbed wire fences. \\ City of words never spoken, \\ Of groans and dark memories. ${ }^{69}$
}

According to Alessandra Mattei, "Hajdari intends the exile as a transposition of the intangible body - the remembrance - outside the original homeland. The voluntary exile is a sort of fertile grave"70 for the poet. Indeed, Hajdari's duty, akin to Grynberg's, is self-sacrificial, in that he has accepted a kind of death in order to continue living, if only to continue a similar process that Migjeni was unable to bring to conclusion: exposing Albanian reality in its minutest detail. "The enverist ${ }^{71}$ slogans have exerted, for half of a century, an astounding psychological terror on psyche of Albanian citizens,"72 Hajdari confesses. "The slogans would be obsessively committed to

${ }^{67}$ Henryk Grynberg, "Writing about Uprootedness," in The Writer Uprooted: Contemporary Jewish Exile Literature, ed. Alvin H. Rosenfeld (Bloomington: Indiana University Press, 2008), 53.

${ }^{68}$ Hajdari, Poesie scelte, 170: "Biongiorno Albania, sono l'Albania."

${ }^{69}$ Ibid, 153.

Dove giaci città degli internati?

Città dei tuoni e dei poeti,

Delle follie e dei suicide.

Perché taci città di Lushnje?

Città degli arresti a note fonda

Di impiccagioni e recinti di filo spinato.

Città di parole mai dette,

di gemiti e memorie oscure.

${ }^{70}$ Alessandra Mattei, "Gëzim Hajdari: On a Poet and His Poetry of Exile," Linguistics and Literature Studies 5, no. 5 (2017): 336.

${ }^{71}$ Here, Hajdari is referring to Albania's communist dictator, Enver Hoxha.

${ }^{72}$ Hajdari, Evviva, 7: "Gli slogan enveristi hanno esercitato, per mezzo secolo, un terrore psicologico impressionante sulla mente dei cittadini albanesi." 
memory, day and night, not only by free citizens, but also by prisoners."73 Grynberg and Hajdari are joined by their lucid chronicling of history and life as they have experienced it, leaving no stone unturned, no name unmentioned. Yet, both authors' scope in this tireless chronicling moves far beyond their own stories, and birthplaces, to represent a basic and decent, as well as universal and timeless, human endeavor. Katarzyna Jerzak describes the scope of Grynberg's writing "superhuman in its focused observations," "74 and quotes the author's increasing awareness, as he ages, that every single thing is important, that it all must be written and recorded. Of Hajdari's long poem Poema dell'esilio (Poema e mërgimit), which is more of a report on the reasons behind his self-imposed exile, Andrea Gazzoni writes that "it is the dwelling of an antipoetic lucidity which records a succession of news events, personal episodes, political and social circumstances, without sparing any dates, places, names, using all potential methods of denunciation and polemics." 75 Indeed, Hajdari begins his "anti-poem," with the following lines:

Kam kontribuar në rrëzimin e diktaturës I have contributed to the collapse of the shqiptare

dhe rindërtimin demokratik të atdheut, sepse aspiroja lirinë

dhe te bukurën, por fitues doli nomenklatura e

djeshme,

përlyer me gjak e krime shteti

Prandaj ndodhem ne ezil, miqtë e mi.

Albanian dictatorship

and the democratic rebuilding of the homeland, because I sought freedom

and beauty, but the winner was yesterday's nomenclature

tainted in blood and the state's crimes

This is why I find myself in exile, my friends. ${ }^{76}$

It continues to tell of Hajdari's founding of an opposition party during the dictatorship, a courageous act at the time, his trials against the post-Communist regime, his refusal to compromise, his public denouncements of the government, and his direct assault on a country where such aggressive, direct confrontation was not tolerated. Hajdari's antipoetic confessions resemble recordings of court proceedings, wherein the poet ensures that all names, places, and details are mentioned. Because he often refers to Albania as Medea throughout his poetic oeuvre, ${ }^{77}$ — "Let that rigid and fertile womb feel pride, Medea, / I am the Poet you dreamed of / on that one wild night;" "You will bow down to me, Medea, / guilty" - Hajdari takes the pains to diligently and explicitly reveal, foregoing metaphor, the reasons behind his antinostalgia. Yet, like Grynberg's oeuvre, much of his oeuvre concerns his homeland and, along with the apparent vitriol, there is

${ }^{73}$ Hajdari, Evviva, 7: "Gli slogan venivano ripetuti a memoria fino all'ossessione, giorno e note, non soltanto dai cittadini liberi, ma anche dai detenuti."

${ }^{74}$ Katarzyna Jerzak, "Henryk Grynberg's Memoirs as Exilic Dialogue," in Diaspora polska w Ameryce Pótnocnej, ed. Rafał Raczyńsky and Katarzyna Morawska (Gdynia: Muzeum Emigracji w Gdyni, 2018): 455.

${ }^{75}$ Andrea Gazzoni, "L'intentio epica dell'esilio: Gëzim Hajdari," Scritture Migranti: Rivista di scambi interculturali 1 (2007): 54, https://www.academia.edu/5758004/Lintentio epica _dellesilio_Gëzim_Hajdari; "è il luogo di una lucidità anti-poetica che contrassegna un succedersi di fatti di cronaca, episodi personali, circostanze politiche e sociali, senza risparmiare date, luoghi, nomi, usando tutte le possibilità della denuncia e della polemica."

${ }^{76}$ Gëzim Hajdari, Poema dell'esilio/Poema e mërgimit (Rimini: Fara Editore, 2005), 10: "sia orgiogloso quell grembo pietroso e fertile, Medea, / son io il Poeta che sognavi / in un'unica note di follia;" "Ti inchinerai davanti a me, Medea, / con senso di colpa."

77 Gazzoni, "L'intentio epica," 57: "L'intreccio tra il mito di Medea e quello di Prometeo, condannato a farsi divorare ogni giorno dal rapace, è una figura ricorsiva nella poesia di Hajdari." 
an underlying longing to help it. Viktor Berberi argues that Hajdari's "entire output can be read as a struggle to restore a voice to the voiceless, whether those suppressed by a brutal dictatorship, those who have been forced to abandon their homelands, or the others left behind to suffer poverty and violence." ${ }^{78}$ Hajdari turns to those whose aim is to forget - "Why are they driven to obliterate memories / and give up their nostalgia?"79 — and encourages them to remember:

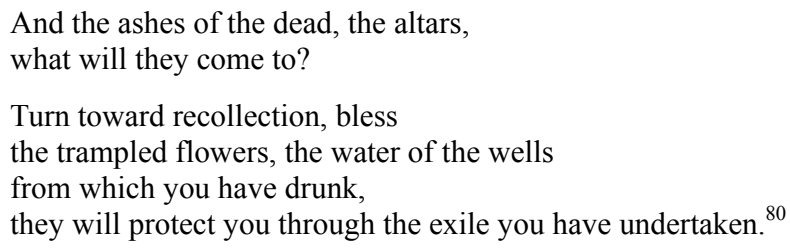

Hajdari's poem clarifies how nostalgia and antinostalgia are rooted in remembrance. Albanian poets lacked freedom of expression during the Communist period. Following the citizens' dislocation in villages, which included the poets, the first sign of the socialist regime's descent into a dictatorship, and the imminent literary catastrophe, occurred in 1961, with the country's official rupture with the Soviet Union: "In '61, the breakdown of political relations with the Soviet Union initiated a heated debate in the literary field between those who wished to maintain the socialist literary tradition and those who wished for a stylistic and thematic renewal. Partisans of the latter were writers Ismail Kadaré, Dritëro Agolli and Fatos Arapi: free verse is adopted, linked to the spontaneity of the oral speech." ${ }^{81}$ Indeed, it is the Albanian poetry written during Communism that most clearly reveals the general impossibility of the rise of the feeling or condition of romanticism in the country, something which was neither entirely inherited nor passed on to the next generation of poets. Ismail Kadare, Albania's most prominent contemporary writer and poet, explains the distinctly unromantic condition and position of an Albanian poet living in Albania at the time as compared to the romanticism of exiles, survivors, glimpsers, those who positioned themselves well in the world and were sufficiently privileged to see beauty in ruins:

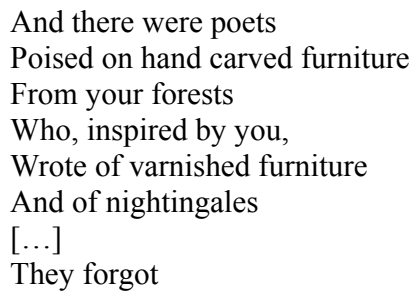

${ }^{78}$ Viktor Berberi, "Notes on the Poem 'The Ones Who Continue to Flee in the Snow' by Gëzim Hajdari," Modern Poetry in Translation 1 (2016), https://modernpoetryintranslation.com/ poem/the-ones-who-continue-to-flee-in-the-snow/.

${ }^{79}$ Gëzim Hajdari, "The Ones Who Continue to Flee in the Snow," Modern Poetry in Translation 1 (2016). https://modernpoetryintranslation.com/poem/the-ones-who-continue-to-flee-inthe-snow/.

${ }^{80}$ Hajdari, "The Ones Who Continue."

81 Toppan, "Gëzim Hajdari," 1: "nel '61 la rottura dei rapporti politici con l'Unione Sovietica dà avvio ad un acceso dibattito in campo letterario tra coloro che desiderano mantenere la tradizione letteraria socialista e coloro che auspicano ad un rinnovamento stilistico e tematico. Partigiani di questa seconda via sono gli scrittori Ismail Kadaré, Dritëro Agolli e Fatos Arapi: viene adottato il verso libero, legato alla spontaneità del discorso orale." 
that in your forests,

From whence the furniture came,

There were many wolves

And few nightingales. ${ }^{82}$

A less fervent reaction, perhaps, than that of Migjeni to the false romanticism of Albania, Kadare, nevertheless ensures that he confirms the historical propaganda with his own seal of disapproval. Dritëro Agolli, a poet whose poems were mostly written during Communism, pens his apology to future poets for his generation's lack of romanticism, in his poem from 1971, "Dy fjalë poetëve që vijnë"/ "A Couple of Words for Poets to Come," while touching on the romanticism of the countryside encouraged by the regime:

Ne s'kemi patur aq kohë të shkruanim për We had no time to write of love. dashurinë,

Megjithëse kemi qenë dashnorë të marrë.

Vendi kërkonte këngë për lirinë,

Vendi kërkonte këngë për bukën që piqej në arë.

Vendi kërkonte nga ne poetët e shkretë

Të drejtonim kurset kundër analfabetizmit,

$[\ldots]$

Ne para jush do ngrihemi të ashpër si asketë,

Të ngarkuar me kallëza gruri dhe hekura të rëndë.

Though we were impetuous lovers.

The country needed songs of freedom.

The country needed songs of grain ripening in

the fields.

The country demanded of us poor poets

That we teach courses to fight illiteracy

[...]

Compared to you we will look like simple monks

Laden with grain and heavy iron chains ${ }^{83}$

Here, Agolli emphasizes a romanticism, subjectivity or sensitivity, of which the poets living in Albania have been historically robbed. This lack of romanticism, a common phenomenon in Albania throughout the years, was merely unearthed as the voice of Albanian poets from within the country became increasingly heard and as they began to write from the perspective of the self: "Could we not at least have written a couple of love poems / Could we not have stammered "Oh my beloved!" / Do not believe we were heartless!". ${ }^{84}$ Agolli concludes his poem. Traces of the rise of antinostalgia among poets like Agolli had already taken place as the Communist regime was coming to an end. The Albanian poet's nostalgia had metamorphosed into antinostalgia. In his poem "A stone or a tree stump," written in 1991, in the eve of the fall of Communism, Dritëro Agolli once more declares his love for his country while simultaneously revealing a sober, disillusioned outlook. More specifically, here Agolli reveals how the country has expulsed him, echoing Hajdari's foremost cause of disquiet:

E dua pa mend vendin tim

Dhe s'gjej një gur a një trung

$\mathrm{Ku}$ të ulem pa brengë e trishtim,

Të mos ulem si murg.

\author{
I love my country \\ But can't find a stone or tree stump \\ To sit without remorse or misery \\ To not sit like a monk. ${ }^{85}$
}

\footnotetext{
${ }^{82}$ Ismail Kadare, "What are these mountains thinking about," in An elusive eagle soars: Anthology of modern Albanian poetry, transl. Robert Elsie (London: Forest Books, 1993), 89-90.

${ }^{83}$ Dritëro Agolli, "A couple of words to poets to come," in An elusive eagle soars: Anthology of modern Albanian poetry, transl. Robert Elsie (London: Forest Books, 1993), 55.

${ }^{84}$ Agolli, "A couple of words," 55.

${ }^{85}$ Dritëro Agolli, "Një gur a një trung," Klasa e letërsisë, audio, 0:41, https://www. klasaletersi.com/d-agolli-nje-gur-a-nje-trung/ [my translation].
} 
A decade later, in his collection entitled "Erbamara" published in 2001, Hajdari asks in wonder "My birthplace, / why this crazy love for you? / You gave birth to me so that I would be your wound." ${ }^{, 86}$ It appears to be the bitter realization that the love-wound attached to one's home never fades, regardless of the treatment that one's home offers. Indeed, for the nostalgic and anti-nostalgic exile, the condition's more superficial layer of rationality differs while the profound, irrational attachment remains for both. While Agolli's verses confirm nostalgia's romanticizing effect, they also reveal a certain level of disillusionment and awareness, indicators of the beginnings of antinostalgia.

Antinostalgia may reflect the frustrations of one whose country's history prevents from becoming the poet one might have been. Indeed, nostalgia and, anti-nostalgia impedes one's journey forward. The Polish poet or writer does not have the same privilege or liberty to direct his gaze on the city, on himself, as the homeland acts as a barrier that delays or permanently prevents the encounter between the exiled poet and his immediate life and the self. "Polish poetry is plugged into society in a way that American poets aren't. I think there's a downside to that, which is that Polish poets themselves, can get caught up in having to articulate the nation's woes, "87 explains Cavanagh. For instance, because Herbert did not dedicate his entire literary output to Poland, he is considered as "this disengaged Parnassian poet, supporting eternal values and ignoring the here-and-now." ${ }^{\circ 8}$ Yet, Herbert does not circumvent a duty more than he prioritizes. Clare Cavanaugh cites Herbert's response in his poem dedicated to Ryszard Krynicki ${ }^{89}$ asking, or rather, stating that if one were to write of the homeland alone, then "aren't we short-changing beauty?". 90 A constant striver, as Stanisław Barańczak describes him, Herbert knew all too well that there were both a larger physical world and a greater inner universe to be encompassed in his interpretation of the world and his literary oeuvre. He understood the vast distance, impossible to transverse, between himself and the Western civilizations of Greece, France or Italy as he confirms in the concluding lines of his poem "Mona Lisa:" "Between the blackness of her back / and the first tree of my life / lies a sword / a melted precipice." ${ }^{.91}$ His visit to Leonardo da Vinci's masterpiece is disillusioning because it serves to highlight the ever-widening — rather than diminishing — gap between the poet and Western cultures. Reaching the west takes him further from his roots and himself while offering no sense of fulfillment. The precipice melts because the poet must start from the very beginning. The road that the poet believed he should follow, the aim he assumed should be fulfilled, vanished in the very moment of his arrival.

In his poem "To Ryszard Krynicki - A Love Letter," which strikingly echoes Agolli's "Two Words for Poets to Come," Herbert laments the assumptions, erroneous beliefs, and destructive consequences of following a distinct ideology, as well as the pains born of these realizations. Specifically, Herbert alludes to the moments, thoughts, words that, albeit inevitably, were tinged by national causes, something that distanced the poets from beauty or truth:

\footnotetext{
${ }^{86}$ Hajdari, Poesie Scelte, 33: "Mia patria, / perché quest'amore folle per te? / Tu mi hai fatto nascere per essere la tua ferita."

${ }^{87}$ Cavanagh, Interview, 88.

${ }^{88}$ Ibid, 81 .

89 A Jewish-Polish writer who was similarly, if not more, censored as Herbert during the Communist years of the People's Poland.

${ }^{90}$ Cavanagh, Interview, 81.

${ }^{91}$ Zbigniew Herbert, Selected Poems, transl. Czesław Miłosz, Peter Dale Scott (New Jersey:
} The Ecco Press, 1968), 87. 


\begin{abstract}
our school notebooks subjected to earnest torture with their traces of sweat tears and blood will be to the eternal proofreader a song without a score nobly righteous and all too self-evident

$[\ldots]$ we came too easily to believe beauty does not save that it leads wantons from dream to dream to death none of us was able to wake the dryad of a poplar or to decipher the handwriting of the clouds

$[\ldots]$ we took public affairs onto our lanky shoulders the battle with tyranny lies the recording of pain but our foes - you admit — were despicably small and so was it worth it to bring down holy speech to rostrum gibberish to a newspaper's black foam

so little joy - sister of the gods - in our poems Ryszard too few glimmering twilights mirrors wreaths ecstasies nothing just obscure psalmodies the whine of animulae urns of ash in a burned-out garden ${ }^{92}$
\end{abstract}

The "burned-out garden," indicates the futility in serving one ideology or another, the European or the Polish, or believing one thing or another. Yet, the position of the Eastern European poet is complex. For a poet like Zbigniew Herbert to ignore the national factor is impossible, not only because underprivileged countries have high expectations of their poets, but also because pretending that the issue does not exist would be insincere and, most importantly, not beneficial personally. Herbert was simultaneously ahead of, and eventually moved beyond, Poland's literary movements, which continued trailing Europe. According to Przemysław Czapliński, it was only in the 1990s, that Poland saw a change in its literary topography, finally headed by works which "represented both a continuation of and a challenge to the tradition of the 'socalled' literature of 'mythic homelands" — a literature of 'small,' 'personal' or minor 'homelands." "93 He further explains:

The contemporary hero of Polish prose, who owes his identity to a private or mythic homeland, no longer defines himself in reference to a larger (regional or national) whole. After all, he inhabits its imagined places, places dependent more on memory than on the historical record, enduring more powerfully in the realm of the spirit than in the realm of the real: malleable spaces, that allow themselves to be shaped by dream and by longing. Today, for a region to be a homeland, it must surrender itself to desire. ${ }^{94}$

In other words, while in Poland, and across the least developed part of Europe, over the last centuries, the poet had to submit to the homeland, in the last few decades, with the rise of exilic experience, the poet has adopted an approach that allows for one's fragments to create a homeland. "In our decade," Czapliński continues, "an important transition has occurred: from the "homeland narrative' to the "narrative homeland." 95 Furthermore, in the late $20^{\text {th }}$ and $21^{\text {st }}$ centuries, the homeland "has revealed itself to be

${ }^{92}$ Zbigniew Herbert, Report from the Besieged City, transl. John and Bogdana Carpenter (New York: Ecco Press, 1985), 14.

${ }^{93}$ Przemysław Czapliński, Karen Underhill, and Tomasz Tabako, "The 'Mythic Homeland' in Contemporary Polish Prose," Chicago Review: New Polish Writing 46, no. 3 \& 4 (2000): 357.

${ }^{94}$ Czapliński, "Mythic Homeland," 363.

${ }^{95}$ Ibid, 365. 
this and only this - a narrative. And it is through this narrative that we create our identity, our roots, our ties to particular regions and to the past." ${ }^{, 96}$ This conclusion stands in contrast to both a nostalgic and antinostalgic condition, as it implies a move beyond these conditions.

Gëzim Hajdari's antinostalgia, as well, at times fades into the poet's contemporary homelessness and his travels to more distant places, like Africa. Hajdari, the poet who grew up in extreme poverty in the remote Albanian village of Darsia, had a long journey ahead of him, in terms of reaching those universal truths that are not necessarily attached to Albania. In his most recent poetry collection, Delta del tuo fiume / Delta of Your River (2015), Hajdari reveals a new attempt to move past the battle waged against his longing for home in order to carve out a new space, a new homeland, a process which, though inevitably attached to his roots, entails a new beginning and, thus, a return. Indeed, this represents the figurative return that takes the exiled poet forward and outward, regardless of origin. Referring to Delta del tuo fiume, Alessandra Mattei writes of Hajdari's struggle and possible triumph:

Being a living body in the poet's world - is expanded in Delta by a lonely corporal
identity in the dynamism of a stateless person, who finds his/her roots in the key
existential experience of the lyric self; this is represented by Albania, a maternal and
creating dimension in its lingual-emotional significance, and by the poetic experience
of other places, seen as stages of the never-ending journey that is becoming a man, as
well as being dweller and beneficiary of the poetry of those traditions which are
invoked in a synchrony of time and space external to any historical and literary
reference but accepted as a personal dimension of creating a poetic sensitivity. ${ }^{97}$

Hajdari does not necessarily find the new homeland in his poetry, but the realization that one must move forward and that "poetic sensitivity" is not a result of European literary movements more than the fact that these movements reflect a process that naturally occurs within the poet, a further exploration of the self. With Delta del tuo fiume, Hajdari moves beyond Albania and beyond antinostalgia, toward something closer to the origin, "in the forest where my soul is exiled." "The poetic work, whilst confirming the ordinary moral guidelines of testimony and remembrance and keeping its own original Albanian identity - also linguistic -," Mattei explains, "develops an open way of thinking and composing; it is dialectically open between the original and final ones that has been never reduced to a global identity in his previous works." 99 As a "villager of Albania," this global identity remained hidden from Hajdari, even after exile. His poem "Fare il contadino della poesia" ("To be the villager of poetry") points at both the desire to start anew, from the roots, as well as his figurative detachment from his homeland. By proclaiming himself a "villager of poetry," Hajdari carefully preserves the poet and the villager in him while elegantly diminishing Albania's role as "the object" of his longing, as the protagonist. Thus, uprooting himself from the Albanian "mud," Hajdari lends Albania its new position in his new global identity. Albania becomes a part of his narrative, rather than vice versa. According to Hajdari, "to be the villager of poetry means to:"

\footnotetext{
${ }^{96}$ Ibid.

${ }^{97}$ Mattei, "Gëzim Hajdari," 337.

${ }^{98}$ Baudelaire, Les fleurs du mal, 76: "dans la forêt où mon esprit s'exile."

${ }^{99}$ Mattei, "Gëzim Hajdari," 337.
} 
tornare all'Essere

riscoprire le radici

bere alla fonte

parlare con i sassi

ascoltare la terra

rileggere il cielo e la terra

$[\ldots]$

sapere chinarsi a raccogliere

chiamare le cose per nome come fanno

muratori,

dire essere un poeta della campagna,

essere allo stesso tempo poeta di campagna e

di città,

mangiare la terra

lavarsi con la terra

$[\ldots]$

essere Uomo return to Being

rediscover the roots

drink at the source

speak with the rocks

listen to the earth

reread the sky and earth

$[\ldots]$

know how to bow to collect

call things by their names, like bricklayers do

say that you are a villager of poetry

be at the same time a poet of the countryside and the city

eat the soil

bathe with soil

[...]

be a Man. ${ }^{100}$

Hajdari "returns" to the village as it is, paradoxically, this village that still conserves his romanticism, his love, his nostalgia, and his longing of a poet. It was the village shaped his original landscape and made him an exile and a poet. Nostalgia, "this provincial evil [which] was meant to become a universalized entity,"101 maintained, like the authors in this study, its provincial roots while becoming transformed in its journey through time and space. Rather than fading, the "unprivileged" writer's patriotic duty metamorphosed from the traditional nostalgic, romantic, patriotic devotion into the writer becoming an authentic envoy of his birthplace.

\section{BIBLIOGRAPHY}

Agolli, Dritëro. "A couple of words to poets to come." In An Elusive Eagle Soars: Anthology of Modern Albanian Poetry, transl. Robert Elsie, 55. London: Forest Books, 1993.

Baudelaire, Charles. Flowers of Evil and Other Works. New York: Dover Publications, 1963.

Berberi, Viktor. "The Great Flight: Refugee Focus," Modern Poetry in Translation 1 (2016). From https://modernpoetryintranslation.com/poem/the-ones-who-continue-to-flee-in-the-snow/ (access on 2.8.2018).

Bloom, Harold and Lionel Trilling. Romantic Poetry and Prose. The Oxford Anthology of English Literature. New York: Oxford University Press, 1973.

Boym, Svetlana. The Future of Nostalgia. New York: Basic Books, 2001. iBooks.

Brodsky, Joseph. "The Condition We Call Exile: An Address." In Altogether Elsewhere, ed. Marc Robinson, 3-10. San Diego: Harcourt Brace \& Company, 1994.

Cavanagh, Claire. "An Interview with Clare Cavanagh.” Interview by W. Martin. Chicago Review: New Polish Writing 46, no. 3 \& 4 (2000): 78-95.

Dibra, Vjollca. "Albanian and English Literature in Light of Comparative Reports." Academic Journal of Interdisciplinary Studies 2, no. 4 (2013).

Elsie, Robert, ed. Anthology of Modern Albanian Poetry: An Elusive Eagle Soars (UNESCO Library of World Poetry). Chester Springs PA: Dufour Editions. 1993.

Elsie, Robert. Migjeni Free Verse, Peja: Dukagjini, 2001.

${ }^{100}$ Gëzim Hajdari, "Fare il contadino della poesia: Un Poema di Gëzim Hajdari," in Patria Letteratura: Rivista internazionale di lingua \& letteratura, 19 December 2014, http://www. patrialetteratura.com/fare-il-contadino-della-poesia-un-poema-di-gezim-hajdari/.

${ }^{101}$ Starobinski, "Il concetto di nostalgia," 91: "questo male provinciale [che] era destinato a divenire un'entità universalizzabile." 
Frashëri, Naim. Bagëti e Bujqësi, 1886. From https://sq.wikibooks.org/wiki/Bagëti_e_Bujqësi (access 12.11.2018).

Gazzoni, Andrea. "L'Intentio epica dell'esilio: Gëzim Hajdari,” Scritture Migranti: Rivista di scambi interculturali. Bologna, 2007. From: https://www.academia.edu/5758004/Lintentio _epica_dellesilio_Gëzim_Hajdari (access 22.11.2018).

Gombrowicz, Witold. A kind of testament. London: Calder \& Boyars, 1973.

Gombrowicz, Witold. Diary Volume One, transl. Lillian Vallee. Evanston: Northwestern University Press, 1988.

Grynberg, Henryk. Antynostalgia. London: Oficyna Poetów i Malarzy, 1971.

Grynberg, Henryk. Monolog polsko-żydowski. Wołowiec: Wydawnictwo Czarne, 2003.

Hajdari, Gëzim. Poema dell'esilio/Poema e mërgimit. Rimini: Fara Editore, 2005.

Hajdari, Gëzim. Evviva il Canto del Gallo nel Villaggio Comunista. Besa Editirice, 2013.

Hajdari, Gëzim. "Fare il contadino della poesia: Un Poema di Gëzim Hajdari," 2015. From: http:/www.patrialetteratura.com/fare-il-contadino-della-poesia-un-poema-di-gezim-hajdari/ (access 3.12.2018).

Hajdari, Gëzim, Poesie Scelte 1990-2015. Nardò: Salento Books, 2015.

Herbert, Zbigniew. Selected Poems, transl. Czesław Miłosz, Peter Dale Scott. New Jersey: The Ecco Press, 1968.

Janion, Maria. "Poland Between the East and the West," transl. Anna Warso. Postcolonial or Postdependancy Studies 1 (2014): 13-33.

Jankélévitch, Vladimir. L'irréversible et la nostalgie. Paris: Flammarion, 1974.

Jerzak, Katarzyna. "Henryk Grynberg's Memoirs as Exilic Dialogue," Disapora Polska w Ameryce Pótnocnej, Gdynia, 2018.

Kadare, Ismail. "What are these mountains thinking about." In An Elusive Eagle Soars: Anthology of Modern Albanian Poetry, transl. Robert Elsie, 88-96. London: Forest Books, 1993.

Koropeckyj, Roman. "Adam Mickiewicz as a Polish National Icon.” In History of the Literary Cultures East-Central Europe, eds. Marcel Cornis-Pope and John Neubauer, 19-39. Amsterdam: John Benjamin's Publishing House, 2004.

Mattei, Alessandra. "Gëzim Hajdari: On a Poet and His Poetry of Exile," Linguistics and Literature Studies 5, no. 5 (2017): 333-343.

Miłosz, Czesław. The Captive Mind. New York: Vintage Books, 1955.

Prete, Antonio. "L'assedio della lontananza." In Nostalgia: Storia di un sentimento, ed. Antonio Prete, 9-31. Milano: Raffaello Cortina Editore, 1992.

Prete, Antonio, ed. Nostalgia: Storia di un Sentimento. Milano: Raffaello Cortina Editore, 1992.

Prifti, Peter R. Encyclopaedia Britannica. "Albanian Literature.” Chicago: Encyclopaedia Britannica. Jul 20, 1998. From: https://www.britannica.com/art/Albanian-literature (access 8.6.2017).

Robinson, Marc, ed. Altogether Elsewhere: Writers on Exile. San Diego: Harcourt Brace \& Company, 1994.

Rousseau, Jean-Jacques. "Il suono natio: Jean-Jacques Rousseau," transl. Antonio Prete. In Nostalgia: Storia di un sentimento, ed. Antonio Prete, 67-68. Milano: Raffaello Cortina Editore, 1992.

Starobinski, Jean. "Il concetto di nostalgia," transl. Alessandro Serra. In Nostalgia: Storia di un sentimento, ed. Antonio Prete, 85-117. Milano: Raffaello Cortina Editore, 1992.

Steinhoff, Eirik, ed. Chicago Review 46, no. 3 \& 4 (2000).

Toppan, Laura. "Gëzim Hajdari (1957-), il poeta dell'esilio." Altriitaliani.net, 2009. From: https://altritaliani.net/wp-content/uploads/pdf_Conf._Laura_su_Hajdari_per_Paris.pdf (access 23.9.2019).

Törnquist-Plewa, Barbara. "Romanticism and Realism in Poland," Scando-Slavica 40 (1994). 


\section{THE UNPRIVILEGED EXILE: FROM NOSTALGIA TO ANTINOSTALGIA AND BEYOND}

"Nostalgia," writes Antonio Prete, quoting Niccolò Tommaseo, "is the noble privilege of poor countries." Though both exile and nostalgia may befall those from more affluent countries and cultures, the conditions are noble and privileged only for those who hail from poor countries which, as Witold Gombrowicz states when referring to Poland, have "a minor role," are doomed to imperfection, and produce less sophisticated men. Polish poet Zbigniew Herbert and Albanian poet Gëzim Hajdari share a similar fate to that of Gombrowicz as they both struggle with the inherent inferiority of their birthplaces and, consequently, experience difficulties in finding a clear position in a globalised world. With very few exceptions, the level of development or affluence of a certain country is closely linked to the nostalgic or antinostalgic feelings experienced by the exiles with both feelings experienced by people from poorer countries. The rise of antinostalgic exiles in the $20^{\text {th }}$ century, like Witold Gombrowicz, Henryk Grynberg, and Gëzim Hajdari, as well as in the $21^{\text {st }}$ century may be an indication of the future of nostalgia or, more specifically, the new face of nostalgia.

KEY WORDS: exile, unprivileged exile, nostalgia, antinostalgia, Polish literature, Albanian literature

\section{NIEUPRZYWILEJOWANE WYGNANIE: OD NOSTALGII DO ANTYNOSTALGII}

Niccolò Tommaseo powiedział, że nostalgia jest szlachetnym przywilejem biednych krajów. Chociaż wygnanie i nostalgia mogą spotkać tych z zamożniejszych krajów i kultur, w których są dobre warunki do życia, jednak wspomniane uprzywilejowanie jest tylko dla tych, którzy pochodzą z biednych krajów. Witold Gombrowicz, rozpatrując to zagadnienie w polskim kontekście, zauważa, że ludzie z tych krajów mają „niewielkie możliwości”; są skazani na niedoskonałość, ponieważ istniejąca w tej przestrzeni rzeczywistość kształtuje mniej wyrafinowanego człowieka. Zbigniewa Herberta, polskiego poetę, i jego albańskiego kolegę po piórze Gëzima Hajdariego łączy z Gombrowiczem podobny los. Zmagają się z wrodzonym poczuciem niższości miejsca swego urodzenia. Mają tym samym trudności z odnalezieniem i określeniem, jako twórcy, swego miejsca w sensie globalnym. Poziom rozwoju lub zamożności danego kraju, z nielicznymi wyjątkami, jest ściśle związany z nostalgicznym lub antynostalgicznym odczuwaniem wygnania. A to oznacza, że wskazane doznania sa doświadczeniem ludzi z biedniejszych krajów. Funkcjonowanie w XX i XXI wieku antynostalgicznych wygnańców takich jak Witold Gombrowicz, Henryk Grynberg i Gëzim Hajdari, może świadczyć o przyszłości nostalgii, a ściślej mówiąc współczesnego oblicza nostalgii.

SŁOWA KLUCZOWE: wygnanie, nieuprzywilejowane wygnanie, nostalgia, antynostalgia, literatura polska, literatura albańska 